\title{
Effect of Colored Plastic Mulches on Yield of Tomato and Weed Biomass
}

\author{
Hamid Reza Rajablariani, Farzad Hassankhan, and Ramin Rafezi
}

\begin{abstract}
In 2010, Tomato (Lycopersicon esculentum L.) was grown on polyethylene mulch films and bare soil for evaluate the effect of colored plastic mulches on weed and crop yield. The plastic mulches were blue, black, clear, red and silver on black. Black and silver/black plastic mulches suppressed weeds which were encouraged under clear, blue and red mulches. Results indicated that soil temperature increased under the various colored plastic mulches about 3 to $6{ }^{\circ} \mathrm{C}$ more than it in bare soil. Number of branches and leaves were better for the plants grown over plastic compared to bare soil. The highest early yield was obtained in clear plastic likely due to light entrance and raising soil temperature. Mulching increased marketable yield relative to bare soil as the plants grown on silver/black plastic mulch indicated a $65 \%$ increasing in marketable mulch compared to control treatment. The plastic mulches resulted in an $84-98 \%$ reduction in weed biomass.
\end{abstract}

Index Terms-Mulching, soil temperature, weed dry weight, early yield.

\section{INTRODUCTION}

Polyethylene mulches are widely used in vegetable production and have contributed significantly to reduction of losses due to weed competition [18]. Film color may affect therefore effective weed seed germination, growth, and development under the plastic [3], [12]. Black polyethylene plastic mulch is the standard plastic mulch used in vegetable production [9]. Researchers using black plastic instead of bare soil have recorded higher yields [17], [19], earlier harvests [15], [16]. Reference [14] reported that tomato grown under irrigation in semi-arid zone of northern Nigeria benefited greatly from mulches. The highest weed dry weight was recorded in transparent plastic mulch and the lowest in black plastic [1]. Black mulch effectively stops weed growth by intercepting nearly all-incoming radiation. Whereas clear mulch absorbs only $5 \%$ of short-wave radiation, reflects $11 \%$, but transmits $84 \%$ of it [24]. Reference [20] obtained the highest yield of Radicchio (Cichorium intybus) in silver plastic mulch. Reference [4] reported earlier harvest of tomato in aluminum, silver and black mulch, respectively. Tomatoes in red mulches set fruit earlier produced more ripe fruit than plants grown in black plastic [10]. Biomass accumulation and flower and fruit production were also

Manuscript received December 1; revised December 24, 2012. This work was supported in part by the Department of Agronomy, Varamin-Pishva Branch, Islamic Azad University, Varamin, Iran.

H. R. Rajablariani and F. Hassankhan are with Department of Agronomy, Varamin-Pishva Branch, Islamic Azad University, Varamin, Iran (e-mail: Larijani2004@gmail.com).

R. Rafezi is with Agriculture and Natural Resources Research Center of Tehran Province, Plant Breeding Department, Karaj, Iran. (e-mail:Raminrafezi@gmail.com). affected by mulch color treatments and may be due to mulch effects on the plant light environment and/or root zone temperatures [5].

The present study was undertaken to evaluate the role of plastic color in growth and yield of tomato grown under low temperature in early spring and arid conditions in summer.

\section{Materials AND MethodS}

Field studies were conducted in spring and summer 2010 (April to July) at Varamin-Pishva Branch, Islamic Azad University, research fields of Agricultural faculty. The mulches were black, blue, clear, red and silver on black plastics. All mulches were laid on $70-\mathrm{cm}$ wide raised bed, using hand. The experimental design was a randomized complete block with five plastic mulches Along with bare soil (weed control and weedy) and 3 replications.

Plots were $6 \mathrm{~m}$ wide and $6 \mathrm{~m}$ long with four double row beds with $150 \mathrm{~cm}$ apart with $35 \mathrm{~cm}$ inter-row spacing and 33 $\mathrm{cm}$ plants spacing to give a density of 4 plants $/ \mathrm{m}^{2} .56$ days old seedlings of tomato cv. Super Chief were transplanted by making holes of $5 \mathrm{~cm}$ diameter on the film and bare ground on the 9th of April. Lateral drip lines having emitters at $10 \mathrm{~cm}$ distance with a discharge rate of 4 liters/ $h$ were placed in each row of plants both in unmulched treatments and below the polyethylene mulch treatments.

Data were recorded on plant height, number of branches and leaves, early and marketable yield using standard methods. Soil temperatures were measured at $10 \mathrm{~cm}$ depth for all treatments using soil thermometer at tow time (8:30 am and 2:30 $\mathrm{pm}$ ) on second day after irrigation. At 35 and 75 DAT (days after transplanting), weed samples were collected from two $50 \mathrm{~cm} \times 50 \mathrm{~cm}$ quadrates randomly laid per plot. The weeds were identified up to species level and were clipped at soil surface, oven-dried at $80^{\circ} \mathrm{C}$ for 48 hours and weighed to determine the dry matter (DM).

Data were analyzed using Proc GLM procedure in the Statistical Analysis System [21].

\section{Results AND Discussion}

\section{A. Soil Temperature}

Due to using plastic mulch soil temperature increased 3.3 to $6.6^{\circ} \mathrm{C}$ compared to without mulch (Table. I). We recorded the highest soil temperature under blue mulch followed by red and clear plastic (30.7, 30.1 and $29.5^{\circ} \mathrm{C}$, respectively). Among plastic mulches, silver/black had the lowest soil temperature. This is consistent with findings of reference [10]. Soil warming at early spring provided suitable conditions for growth of tomato seedlings and earliness, but 
also weeds germinated and grew under plastic. Reduce temperature in the silver/black mulch at the end of growing season increased plants survival.

TABLE I: SOIL TEMPERATURE AT 10 CM DEPTH IN MULCHED TREATMENTS

\begin{tabular}{lccc}
\multicolumn{4}{c}{ AND BARE SOIL } \\
\cline { 2 - 4 } \multicolumn{1}{c}{ Treatments } & \multicolumn{3}{c}{ Soil temperature $\left({ }^{\circ} \mathrm{C}\right)$} \\
\hline Clear & 25.00 & $14: 00$ & Mean \\
Black & $24.5 \mathrm{~b}$ & $33.1 \mathrm{~b}$ & $29.5 \mathrm{~b}$ \\
Red & $26.3 \mathrm{a}$ & $34.0 \mathrm{c}$ & $27.6 \mathrm{c}$ \\
Blue & $26.4 \mathrm{a}$ & $35.0 \mathrm{a}$ & $30.1 \mathrm{ab}$ \\
Silver/black & $24.1 \mathrm{~b}$ & $30.7 \mathrm{c}$ & $27.4 \mathrm{c}$ \\
Bare soil (control) & $21.3 \mathrm{c}$ & $26.8 \mathrm{~d}$ & $24.1 \mathrm{~d}$ \\
Weedy & $20.4 \mathrm{c}$ & $25.7 \mathrm{~d}$ & $23.0 \mathrm{~d}$ \\
\hline \hline In a column, figures bearing same letter(s) do not differ significantly \\
at 5\% level of probability by DMRT.
\end{tabular}

\section{B. Plant Height}

Mulch color had significant effects on plant height. At the fruit maturity (75 DAT), the highest plant heights were observed in blue and silver/black plastic mulches (Fig. 1). According to finding of reference [9], blue plastic mulch produced plant height, fresh weight, and early and total yield comparable to black plastic. It is possible that the FR:R ratio and blue light reflected from the plastic mulches could have improved okra growth and yield. According to reference [5] in red bell pepper, plants grown in red mulch were taller than the other colored mulch treatments. Mulch color effects on internodes length suggested a role for surface reflected light (and particularly the far-red to red light ratio) on tomato plant development. Reference [7] and reference [13] found the FR:R ratio had a positive effect on vegetable crops.

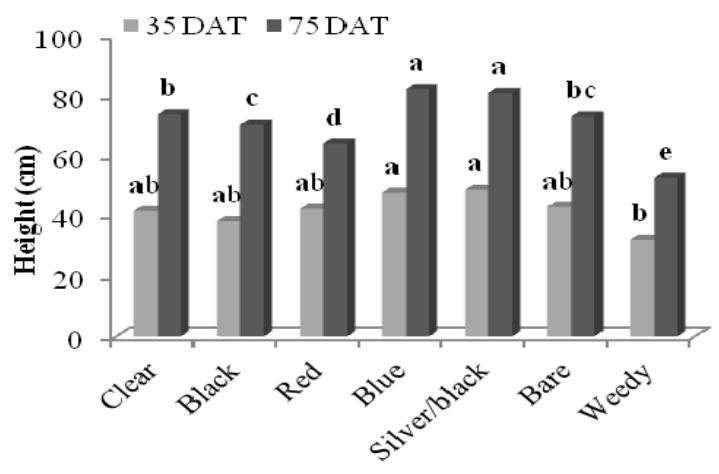

Fig. 1. Effect of colored plastic mulches on plant height.

\section{Number of Branches}

Mulching significantly increased number of branches compared to bare soil (Fig. 2). It was reported that mulched tomato plants had more branches than that of unmulched plants, which supported the present results [2].The plants grown on blue and silver/black plastic mulch produced the most number of branch, respectively.

\section{Number of Leaves}

The plants grown over plastic mulches considerably produced the most number of leaves relative to control treatment (Fig. 2). At 75 DAT the number of leaves per plant was reduced. However, the maximum number of leaves per plant was found on the plants mulched with silver/black plastic at second sampling, followed by the black and blue plastic mulch (60, 57.3 and 55.3 per plant, respectively). The microclimate condition improved by the mulches might have provided a suitable condition for producing higher number of leaves in the plants. Reference [8] reported that lettuce (Lactuca sativa) grown on red mulch had most number of leaves compared to the other colored mulch treatments.
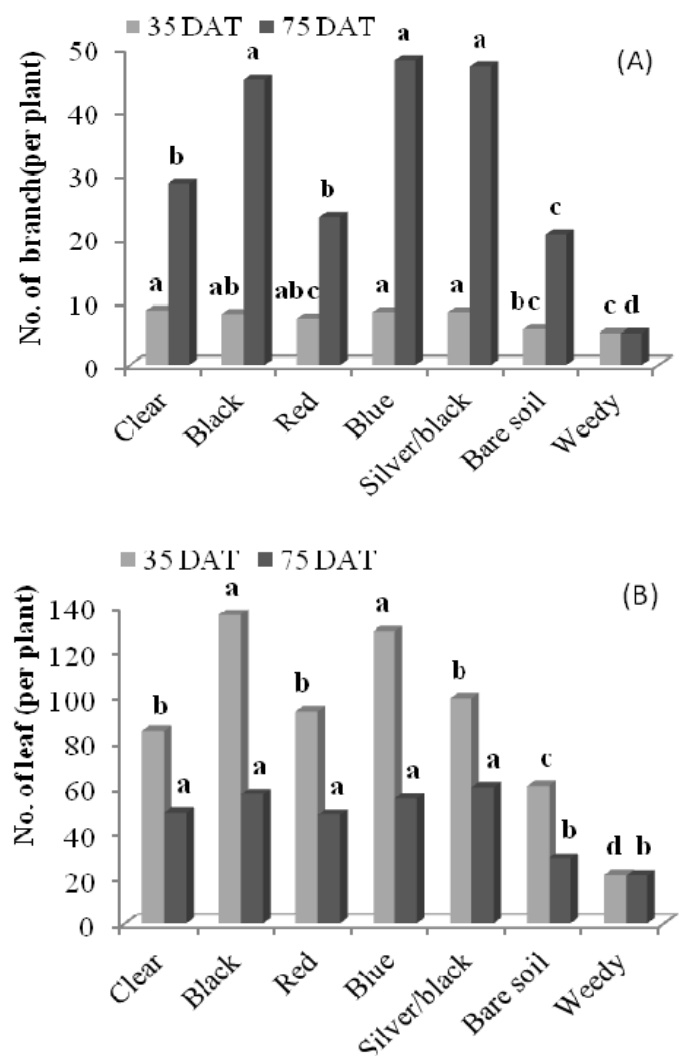

Fig. 2. Effect of experimental treatments on number of branches (A) and number of leaves (B).

\section{E. Early Yield}

The surface color of plastic mulch can change the quantity of light and spectral balance reaching plants, with resulting effects on growth and fruit production [6], [7]. In the other hand, plastic mulches often enhanced soil temperatures under the mulch covering and provided plants an early season growth boast [23]. Our results showed that plants grown over clear mulch had the highest early yield (1820 kg/ha), whereas tomatoes grown over black and silver/black produced lower early yield (Fig. 3). Reference [4] reported that early yields were higher from plants grown on aluminum, red and black mulch than plants grown on white, green and brown.

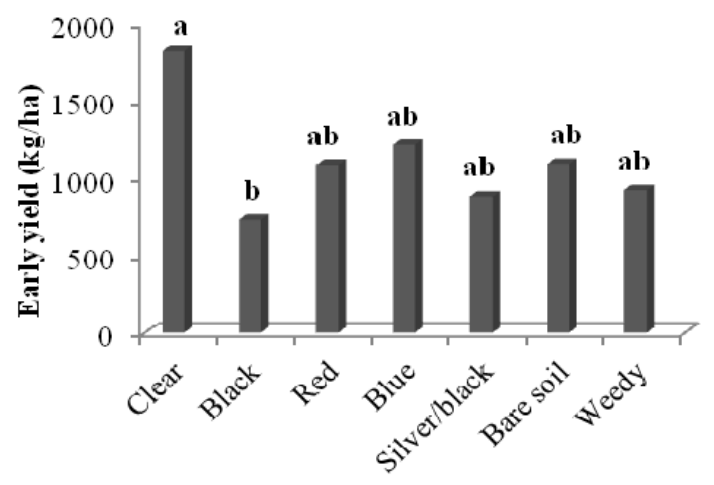

Fig. 3. Effect of different treatments on early yield. 


\section{F. Marketable Yield}

All colored plastic mulch significantly had higher marketable yield compared to bare soil. Marketable yield increased by $65 \%$ in silver/black followed black (50\%), blue (40\%), red (26\%) and clear plastic mulch (24\%). The increase in yield of mulched plot was probably associated with the conservation of moisture and improved microclimate both beneath and above the soil surface and great weed control, spacialy in silver/black and black plastic mulch. Reference [25] found that use of black polyethylene mulch plus drip irrigation further raised the tomato yield by $57.87 \mathrm{t} / \mathrm{ha}$.

The lowest marketable yield was also obtained in weedy plots, due to severe competition of weeds with tomato plants.

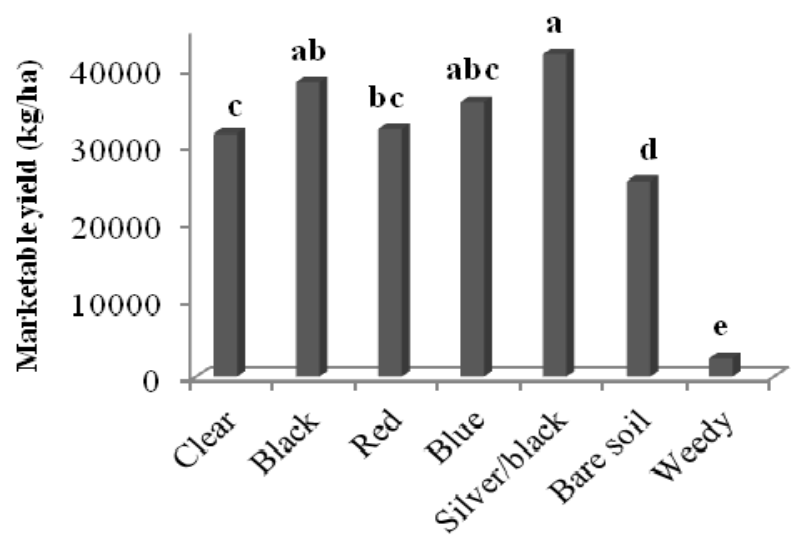

Fig. 4. Effect of different treatments on marketable yield.

\section{G. Weed Dry Weight}

TABLE II: EFFECT OF DIFFERENT TREATMENTS ON WEED DRY WEIGHT AT 35 AND 75 DAT

\begin{tabular}{lccc}
\hline \multirow{2}{*}{ Treatments } & \multicolumn{2}{c}{ Weed dry weight $\left(\mathrm{g} / \mathrm{m}^{2}\right)$} & \\
\cline { 2 - 3 } & 35DAT & $75 \mathrm{DAT}$ & Control (\%) \\
\hline Clear & $96.0 \mathrm{~b}$ & $124.3 \mathrm{~b}$ & $85 \mathrm{bc}$ \\
Black & $29.0 \mathrm{bc}$ & $38.9 \mathrm{bc}$ & $95 \mathrm{abc}$ \\
Red & $89.0 \mathrm{~b}$ & $130.0 \mathrm{~b}$ & $84 \mathrm{c}$ \\
Blue & $63.5 \mathrm{bc}$ & $87.4 \mathrm{bc}$ & $89 \mathrm{abc}$ \\
Silver/black & $9.0 \mathrm{c}$ & $13.9 \mathrm{bc}$ & $98 \mathrm{ab}$ \\
Bare soil & $0.0 \mathrm{c}$ & $00.0 \mathrm{c}$ & $100 \mathrm{a}$ \\
Weedy & $622.2 \mathrm{a}$ & $803.4 \mathrm{a}$ & $00.0 \mathrm{~d}$ \\
CV (\%) & 26.3 & 19.8 & 6.2 \\
\hline \hline
\end{tabular}

In a column, figures bearing same letter(s) do not differ significantly at $5 \%$ level of probability by DMRT.

Table II shows clear, red and blue plastic mulches produced maximum weed which might be due to direct entrance of solar radiation through them and as well as due to high soil temperature and soil moisture content under plastic, especially at the upper $5 \mathrm{~cm}$ depth. However, at 35 and 75 DAT the highest weed dry weight among mulches was recorded in blue and clear mulches (96 and $130 \mathrm{~g} / \mathrm{m}^{2}$, respectively) and between treatment was observed in weedy plot $\left(803.4 \mathrm{~g} / \mathrm{m}^{2}\right)$. Plastic mulches reduced weed dry weight by $98,95,89,85$ and $84 \%$ for silver/black, black, blue, clear and red, respectively relative to weedy plots, which weeding was manually done five times during of experimentation. The black plastic mulch resulted in an $80 \%$ reduction in weed biomass [11]. Reference [18] reported that the highest and lowest weed biomass in white and black plastic mulches, respectively. The silver/black and black plastic mulch blocked the weeds, except a few, which emerged through the planting holes. This result is consistent with the findings of Reference [22] and [1]. Similar results were found for weed density.

\section{CONCLUSION}

In this study, plants grown on plastic mulches produced more number of branches and leaves than those in bare soil. The use of plastic mulch increased soil temperature 3.3 to $6.6^{\circ} \mathrm{C}$ compared to without mulch. The silver/black and Black plastic mulch controlled weeds by 95 to $98 \%$. The light transmitter plastics advanced earliness and the highest early yield was obtained in clear plastic mulch. This can be attributed to increase soil temperature under plastic, when air temperature was low at early spring. The marketable yield was greater with the use of plastic mulches (up to 24 to 65\%) compared to bare soil. The increase in yield of mulched plots was probably associated with the conservation of moisture, improved microclimate both beneath and above the soil surface, light reflection and great weed control, spacialy in silver/black plastic mulch.

\section{REFERENCES}

[1] M. Ashrafuzzaman, M. Abdul hamid, M. R. Ismail, and S. M. Sahidullah, "Effect of Plastic Mulch on Growth and Yield of Chilli (Capsicum annuum L.),” Brazilian Arshivesof Biology and Technology, vol. 54, no. 2, pp. 321-330, 2011.

[2] R. O. Awodoyin, F. I. Ogbeide, and O. Oluwole, "Effects of Three Mulch Types on the Growth and Yield of Tomato (Lycopersicon esculentum Mill.) and Weed Suppression in Ibadan, Rainforest-savanna Transi-tion Zone of Nigeria,” Tropical Agricultural Research \& Extension, vol. 10, pp. 53-60, 2007.

[3] D.Brault, K. A. Stewart, and S. Jenni, "Optical properties of paper and polyethylene mulches used for weed control in lettuce,” HortScience, vol. 37, pp. 87-91, 2002.

[4] J. E. Brown, W. D. Goff, J. M. Dangler, W. Hogue, and M. S. West, "Plastic mulch color inconsistently affects yield and earliness of tomato," HortScience, vol. 27, no. 10, pp. 1135, 1992.

[5] D. M. Decoteau, "The emergence and early development of colored reflective plastic mulch technology in agriculture," Recent Advances in Agriculture, 2008

[6] D. R Decoteau, M. J. Kasperbauer, D. D. Daniels, and P.G. Hunt, "Plastic mulch color effects on reflected light and tomato plant growth,” Scientia Hort., vol. 34, pp. 169-175, 1988.

[7] D. R. Decoteau, , M. J. Kasperbauer, and P. G. Hunt, "Mulch surface color affects yield of fresh market tomatoes” J. Amer. Soc. Hort. Sci., vol. 114, pp. 216-220, 1989.

[8] E. D. Franquera, "Influence of Different Colored Plastic Mulch on the Growth of Lettuce (Lactuca sativa)," Journal of Ornamental and Horticultural Plants, vol. 1, no. 2, pp. 97-104, September 2011.

[9] G. G. Gordon, G. W. Foshee, S. T. Reed, J. E. Brown, and E. L. Vinson, "The Effects of Colored Plastic Mulches and Row Covers on the Growth and Yield of Okra,” HortTechnology, vol. 20, no. 1, pp. 224-233, February 2010.

[10] R. E. Gough, "Color of plastic mulch affects lateral root development but not root system architecture in pepper,” HortScience, vol. 36, pp. 66-68, 2001.

[11] E. M. Grassbaugh, E. E. Regnier, and M. A. Bennett, "Comparison of Organic and Inorganic Mulches for Heirloom Tomato Production,” in Proc. XXVI IHC - Sustainability of Horticultural Systems, Eds. L. Bertschinger and J.D. Anderson Acta Hort. 2004, pp. 638, ISHS.

[12] J. M. Ham, G. Kluitenberg, and W. Lamont, "Optical properties of plastic mulches affect the field temperature regime," Journal of the American Society for Horticultural Science, vol. 118, pp. 188-188, 1993.

[13] H. A. Hatt, M. J. McMahon, D. E. Linvill, and D. R. Decoteau. "Influence of spectral qualities and resulting soil temperatures of mulch 
films on bell pepper growth and production," in Proc. Natl. Agr. Plastics Congr, vol. 24, 1993, pp. 233-238.

[14] A. I. Hudu, K.N. Futuless, and N. A. Gworgwor, "Effects of mulching intensity on the growth and yield of irrigated tomato (Lycopersicon esculentum Mill.) and weed infestation in semi-arid zone of Nigeria” Journal of Sustainable Agriculture, vol. 21, pp. 37-45, 2002.

[15] L. Iharra, J. Flores, and J. C. Diaz-Pérez, "Grow and yield of muskmelon in response to plastic mulch and row covers" Scicntia Hort, vol. 87, pp.139-145, 2001.

[16] W. J. Lamont, "Plastic mulches for production of vegetable crops," HortTechnology, vol. 3, no. 1 pp. 35-39, 1993.

[17] B. Mirshekari, H. R. Rajablarijani, M. AghaAlikhani, F. Farahvash, and V. Rashidi, "Evaluation of biodegradable and polyethylene mulches in sweet corn production," International Journal of Agriculture and Crop Sciences, vol. 4, no. 20, pp. 1540-1545, 2012.

[18] M. Ngouajio and J. Ernest, "Light transmission through colored polyethylene mulches affected weed population" HortScience, vol. 39, no. 6 pp. 1302-1304, 2004.

[19] H. R. Rajablarijani and M. Aghaalikhani, "Non-Chemical Weed Control in Winter Canola (Brassica napus L.)," in Proc. 2nd International Conference on Agricultural and Animal Science. IPCBEE, vol. 22, pp. 30-34, 2011.

[20] A. Rangarajan, and B. Ingall, "Mulch Color Affects Radicchio Quality and Yield," Hortscience, vol. 36, no. 7, pp. 1240-1243, 2001.

[21] SAS Institute, Inc. SAS user's guide: Statistics. Version 9.0. SAS Institute, Inc., Cary, NC. 2002.
[22] M. W. Schonbeck, "Weed suppression and labor costs associated with organic, plastic, and paper mulches in small-scale vegetable production,” J. Sustain. Agric., vol. 13, pp. 13-33, 1999.

[23] H. G. Taber, "Effect of plastic soil and plant covers on Iowa tomato and muskmelon production," in Proc. Nat. Agr. Plastic Cong. 17, pp. 37-45,1983.

[24] J. M. Tarara, "Microclimate Modification with plastic mulch," Hortscience, vol. 35, no. 2, pp. 222-228, 2000.

[25] R. Singh, S. Kumar, D. D. Nangare, and M. S. Meena, "Drip irrigation and black polyethylene mulch influence on growth, yield and water-use efficiency of tomato," African Journal of Agricultural Research, vol. 4, no.12, pp. 1427-1430, December, 2009.

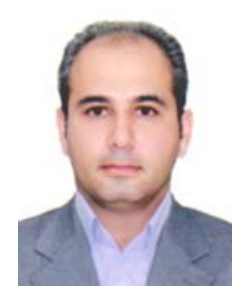

Hamid Reza Rajablarijani. was born in Iran. He was awarded his Bachelor's and Master's Degrees in Agronomy from the Department of Agronomy, Faculty of Agriculture, Varamin-Pishva Branch, Islamic Azad University, Iran in 1995 and 2003, respectively. He is $\mathrm{PhD}$ student at Tabriz Branch, Islamic Azad University, Department of Agronomy and plant breeeding, Faculty of Agriculture. He also is an Academic Lecturer within Department of Agronomy, Faculty of Agriculture, Varamin-Pishva Branch, Islamic Azad University. His research interests are weed biology, ecology and management and mulching. 